\title{
Müllerian inhibiting substance inhibits an ovarian cancer cell line via $\beta$-catenin interacting protein deregulation of the Wnt signal pathway
}

\author{
SANG HO PARK ${ }^{1}$, YOUN JEE CHUNG ${ }^{1}$, JAE YEN SONG $^{1}$, SANG IL KIM ${ }^{1}$, DAVID PÉPIN ${ }^{1}$, \\ DAVID T. MacLAUGHLIN ${ }^{2}$, PATRICIA K. DONAHOE ${ }^{2}$ and JANG HEUB KIM ${ }^{1}$
}

\author{
${ }^{1}$ Department of Obstetrics and Gynecology, College of Medicine, The Catholic University of Korea, Seoul 137-140, \\ Republic of Korea; ${ }^{2}$ Pediatric Surgical Research Laboratories, Massachusetts General Hospital, \\ Harvard Medical School, Boston, MA 02114, USA
}

Received October 5, 2016; Accepted February 2, 2017

DOI: 10.3892/ijo.2017.3874

\begin{abstract}
Müllerian inhibiting substance/anti-Müllerian hormone (MIS/AMH) has been suggested as a biotherapeutic agent in gynecological cancers that highly express the MIS/ AMH type II receptors (MISRII/AMHRII) but the anticancer mechanisms by which MIS/AMH acts are not fully understood. Our experiments show that MIS/AMH inhibits ovarian cancer by deregulating the Wnt signal pathway via the $\beta$-catenin interacting protein (ICAT). MIS/AMH inhibition of ICAT by small interfering RNAs (siRNA) decreased ICAT driven ovarian cancer cell viability as measured by the methylthiazoltetrazolium assay, reversed cell cycle arrest and Annexin V expression and diminished migration by scratch wound assay. Changes in expression of regulatory proteins were shown by western blotting. We determined that MIS/AMH upregulated ICAT in ovarian cancer cell line which caused decreased cell viability, cell cycle arrest and apoptosis. This effect, however, was blocked when ICAT was downregulated by siRNA. The present study demonstrates a role for ICAT in MIS/AMH mediated inhibition of the Wnt signaling pathway in ovarian cancer.
\end{abstract}

Correspondence to: Professor Jang Heub Kim, Department of Obstetrics and Gynecology, Seoul St. Mary's Hospital, College of Medicine, The Catholic University of Korea, 505 Banpo-dong, Seocho-gu, Seoul 137-140, Republic of Korea

E-mail: janghkim@catholic.ac.kr

Abbreviations: MIS/AMH, Müllerian inhibiting substance/antiMüllerian hormone; MISRII, MIS type II receptor; ICAT, $\beta$-catenin interacting protein; siRNA, interfering RNAs; SRY, sex determining region of the $\mathrm{Y}$ chromosome; $\mathrm{CDK}$, cyclin dependent kinase

Key words: Müllerian inhibiting substance, anti-Müllerian hormone, ovarian cancer, Wnt signal pathway, ICAT, CTNNBIP1 protein ( $\beta$-catenin interacting protein)

\section{Introduction}

In eutherian mammals, the chromosomal sex is determined at fertilization and sexual differences begin after the 7th week in humans when the sex determining region of the Y chromosome (SRY) is activated. The next stage of sex differentiation, Müllerian duct regression and Wolffian duct development, rely on two hormones: testosterone, secreted by Leydig cells and Müllerian inhibiting substance, also named anti-Müllerian hormone (MIS/AMH), produced by Sertoli cells (1). MIS/AMH was first suggested by Alfred Jost in the late 1940s (2) showing that a testicular product different from testosterone which he named 'Müllerian inhibitor', was responsible for the regression of Müllerian ducts in the male fetus (3).

MIS/AMH is a member of the transforming growth factor- $\beta$ super-family of growth and differentiation response modifiers through binding two similar type I and type II receptors (4). MIS/AMH from testicular Sertoli cells, causes regression of the Müllerian ducts that are the precursors to the Fallopian tubes, the surface epithelium of the ovaries, the uterus, the cervix, and the upper third of the vagina in male embryos (5). It is expected to inhibit the growth of gynecological cancers, because the three most common gynecological cancers, ovarian, endometrial (uterine) and cervical cancer, originate from Müllerian duct-derived tissues (6-8). MIS/AMH type II receptors (MISRII/AMHRII) which bind MIS/AMH, have been shown to be expressed in gynecological cancers, whreas their expression is low in normal tissues $(9,10)$. It was previously shown that MIS/AMH inhibited growth of gynecological cancer cells by regulating cell cycle, apoptosis and Wnt signaling pathways (11-13). From among these pathways, cell cycle arrest is regarded as playing a major role in MIS/AMH-mediated signal transduction cascades in gynecological cancer. MIS/AMH upregulates expression of p16, pRB-related proteins, and some E2F family members, and induces G1 arrest and subsequent apoptosis $(5,11,13,14)$. Furthermore, Wnt signaling pathway also has an important role in both embryonic development and tumorigenesis $(15,16)$. $\beta$-catenin, a key component of the Wnt signaling pathway, interacts with the TCF/LEF family of transcription factors 
and activates transcription of Wnt target genes which in turn regulates proliferation, polarity, adhesion and motility (17). It was also demonstrated in human epithelial ovarian cancer cell lines, that ovcar-8 expresses highly MISRII/AMHRII and shows high susceptibility to MIS/AMH $(13,18)$.

In our previous study in endometrial cancer, we showed upregulation by MIS/AMH treatment of the $\beta$-catenin interacting protein (ICAT) (11) which was found to negatively regulate the Wnt signaling pathway by inhibiting the interaction between $\beta$-catenin and TCF family members (19). To understand how MIS/AMH regulates $\mathrm{Wnt} / \beta$-catenin in gynecological cancers, we show that MIS/AMH upregulates ICAT expression which results in ovarian cancer growth by disruption of the $\beta$-catenindependent Wnt signaling pathway.

\section{Materials and methods}

Recombinant human MIS/AMH. Recombinant human MIS/AMH was purified and its biological activity was confirmed in the Pediatric Surgical Research Laboratories at the Massachusetts General Hospital (Boston, MA, USA) from serum-free and serum containing conditioned media as previously described (20).

Cells and cell culture. The human ovarian cancer cell line ovcar-8 (Pediatric Surgical Research Laboratories, Massachusetts General Hospital) was maintained in Dulbecco's modified Eagle's medium and $10 \%$ fetal bovine serum (FBS), $1 \%$ penicillin/streptomycin and $1 \%$ L-glutamine for no more than 8 passages and subcultures were initiated at $80 \%$ confluence. The cultures were maintained in a humidified atmosphere of $5 \% \mathrm{CO}_{2}$ at $37^{\circ} \mathrm{C}$.

Transfection of siRNA. The small interfering RNA (siRNA) targeted against human ICAT gene silencer (acceccion number NM_001012329), siRNA transfection reagent, and serum-free transfection medium were purchased from Qiagen (Mansfield, MA, USA). The day before the transfection, $1 \times 10^{5}$ cells were seeded in each well of 6-well cell culture plates in antibioticfree medium. The next day, cells were washed with transfection medium and transfection complexes were prepared using ICAT siRNA, siRNA transfection reagent, and transfection medium according to the manufacturer's instructions and were delivered to cell monolayers in $1 \mathrm{ml}$ fresh media with $20 \mathrm{nM}$ final concentration of siRNA. The siRNAs used were as follows: ICAT was silenced in ovcar-8 (siICAT/ovcar-8) using FlexiTube siRNA (Hs_CTNNBIP1_2); the target sequence is 5'-TCCCTTCAGACTGGCCCTTAA-3' (Qiagen cat. no. SI00125734) as previously shown. Non-silencing negative control (con/ovcar-8) used AllStars Neg Control siRNA (Qiagen cat. no. I027281).

Methylthiazol tetrazolium (MTT) assay. Three thousand cells/well were seeded in 96-well plates. After $24 \mathrm{~h}$ the cells were exposed to vehicle control or $10 \mu \mathrm{g} / \mathrm{ml}$ ) of MIS/AMH for 48 h. Cells were washed with phosphate-buffered saline (PBS) and $100 \mu \mathrm{l}$ of MTT solution $(5 \mathrm{mg} / \mathrm{ml}$ MTT stock in PBS diluted to $1 \mathrm{mg} / \mathrm{ml}$ with $10 \%$ DMEM) was added to each well. Cells were incubated for $4 \mathrm{~h}$ at $37^{\circ} \mathrm{C}$ at the end of which time $200 \mu$ l dimethyl sulfoxide (DMSO; Sigma-Aldrich,
St. Louis, MO, USA) was added and incubated further for $30 \mathrm{~min}$ at room temperature in the dark. Optical densities at $550 \mathrm{~nm}$ were measured using an ELISA plate reader (BioTek Instruments, Winooski, VT, USA).

Scratch wound migration assay. One hundred percent confluent ovcar- 8 monolayers were used and the scratch assay performed using a sterile $200-\mu$ l pipette tip to scratch the cells to form a cell-free gap. The cells were then cultured in $10 \%$ FBS medium contained vehicle or $10 \mu \mathrm{g} / \mathrm{ml}$ of MIS/AMH and fixed with formalin. Migration of wounded cells was evaluated at 0 and $48 \mathrm{~h}$ with an inverted Olympus phase-contrast microscope. The six different wells were scratched at the same time in two independent experiments and migration was determined using the Image J program as an average closed area of the wound relative to the initial scratch area at $48 \mathrm{~h}$ after wounding.

Cell cycle analysis. Ovcar-8 cells were exposed to $10 \%$ FBS medium with $10 \mu \mathrm{g} / \mathrm{ml}$ MIS/AMH or vehicle control buffer for $48 \mathrm{~h}$ and the cells were collected by trypsinization. The cells were fixed with $100 \%$ methanol and stored for $30 \mathrm{~min}$ at $20^{\circ} \mathrm{C}$ and washed with PBS. Following centrifugation the cells were re-suspended in $1 \mathrm{ml}$ DNA staining solution $(20 \mu \mathrm{g} / \mathrm{ml}$ propidium iodide, $200 \mu \mathrm{g} / \mathrm{ml}$ DNase free RNase) and incubated in the dark at $37^{\circ} \mathrm{C}$ for $30 \mathrm{~min}$. The cells were analyzed on a FACSVantage SE flow cytometer (Becton-Dickinson, San Jose, CA, USA). The forward scatter and red fluorescence above $600 \mathrm{~nm}$ were measured and the results analyzed using CellQuest $^{\mathrm{TM}}$ software (Verity Software House, Inc., Topsham, ME, USA).

Annexin $V$ analysis. The MIS/AMH treated cells were stained for Annexin V and propidium iodide (PI) using the Annexin V-FITC apoptosis detection kit I (556547; BD Biosciences, San Diego, CA, USA) according to the manufacturer's protocol. Briefly, following drug treatment for $48 \mathrm{~h}$, $1 \times 10^{5}$ cells were pelleted and washed once with PBS and re-suspended in $100 \mathrm{ml}$ of binding buffer [10 $\mathrm{mM}$ HEPES ( $\mathrm{pH} 7.4$ ), $150 \mathrm{mM} \mathrm{NaCl}, 5 \mathrm{mM}$ potassium chloride, $1 \mathrm{mM}$ $\mathrm{MgCl}_{2}$ and $2 \mathrm{mM}$ calcium chloride]. Subsequently, $5 \mu \mathrm{l}$ of Annexin V-FITC and PI was added to the cells that were then incubated for $15 \mathrm{~min}$ at room temperature in the dark. After this incubation, $400 \mu \mathrm{l}$ of binding buffer was added and cells were analyzed using a FACSVantage SE flow cytometer (Becton-Dickinson). Data analyses were conducted using CellQuest software.

Western blot analysis. Proteins from cells treated with $10 \mu \mathrm{g} / \mathrm{ml}$ MIS/AMH were harvested in RIPA buffer $(150 \mathrm{mM}$ $\mathrm{NaCl}, 1 \% \mathrm{NP}-40,0.5 \%$ sodium deoxycholate, $0.1 \%$ SDS and $50 \mathrm{nM}$ Tris- $\mathrm{HCl}$ ) with $1 \mu \mathrm{M}$ PMSF and the protein concentration was determined by BCA protein assay reagent (23225; Thermo Fisher Scientific, Waltham, MA, USA). Equal amounts of protein were separated on SDS-polyacrylamide gels (50 $\mu \mathrm{g}$ per lane) and transferred to PVDF membrane. The blots were blocked in TBS-T (20 mM Tris-HCl, $\mathrm{pH} 7.6$, $137 \mathrm{mM} \mathrm{NaCl}, 0.1 \%$ Tween-20) containing 5\% powdered milk for $1 \mathrm{~h}$ and then incubated in 5\% powdered milk TBS-T at $4^{\circ} \mathrm{C}$ overnight with the primary antibodies, ICAT (1:100, sc-99240; 


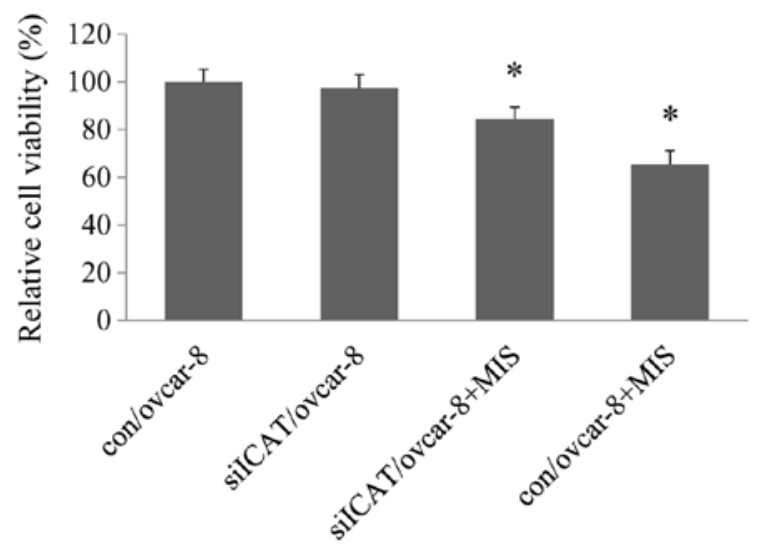

Figure 1. Effect of MIS/AMH on the viability of the ovcar- 8 ovarian cancer cell line. Results are presented as percentage of control which was calculated using the equation: (mean absorbance of treated cells/mean absorbance of control cells) $x$ 100. Data are expressed as mean \pm standard deviation (SD) from four independent experiments. ${ }^{*} \mathrm{P}<0.05$ as compared to corresponding control group, $\mathrm{n}=9$ per group.

Santa Cruz Biotechnology, Santa Cruz, CA, USA), caspase-3 (1:200, 9668; Cell Signaling Technology, Inc., Boston, MA, USA), Apaf-1 (1:100, sc-8339; Santa Cruz Biotechnology), E2F1 (1:200, 3742; Cell Signaling Technology), p107 (1:100, sc-318; Santa Cruz Biotechnology), c-Myc (1:200, 5605; Cell Signaling Technology), phospho-c-Jun (1:200, 3270; Cell Signaling Technology), $\beta$-catenin (1:200, 9562; Cell Signaling Technology), beclin-1 (1:200,3495; Cell Signaling Technology) and LC3A/B (1:200, 12741; Cell Signaling Technology). Blots were then washed three times with $1 \%$ TBS-T and incubated with the corresponding horseradish peroxidase-conjugated secondary antibody, diluted to $1: 5,000$ in $1 \%$ non-fat dry milk TBS-T. Blots were detected using the Pierce ECL western blotting substrate (Thermo Fisher Scientific).

Statistical analysis. MTT results are presented as percentage of control, which was calculated using the following equation: (mean absorbance of treated cells/mean absorbance of control cells) x 100. Data are expressed as mean \pm SD from nine independent experiments. A $\mathrm{P}<0.05$ was considered statistically significant when compared with corresponding vehicle control cells. Cell cycle distribution after exposure to MIS/AMH in ovarian cancer cells are presented as histograms of the mean \pm SD from three independent experiments. Annexin V analysis was done for evaluation of apoptosis. Quadrant rectangular dot grams from a representative of three independent experiments are shown. Western blotting results were presented as mean \pm SD from three independent experiments. Statistical comparisons between two experimental groups were performed using Student's t-test (paired) whilst multiple group comparisons were performed using analysis of variance (ANOVA). Data were regarded as being significant at $\mathrm{P}<0.05$.

\section{Results}

ICAT siRNA reverses the inhibition effect of MIS/AMH on ovcar-8 cells. There were no significant differences between
siRNA-transfected cells and untransfected controls (data not shown). Upon MIS/AMH expose, the viability of OVCAR-8 cells decreased by $\sim 65.34 \%$ relative to MIS/AMH untreated control and siICAT/ovcar-8 cells, but when treated with ICAT-specific siRNA inhibition was reduced to $84.51 \%$ in MIS/AMH treated siICAT/ovcar- 8 cells. The inhibitory effect of MIS/AMH on ovcar- 8 cell viability was reduced by $19.17 \%$ in the siCAT/ovcar-8 group compared to the con/ovcar-8 group (Fig. 1).

ICAT siRNA reduces the effect of MIS/AMH on migration. The scratch wound migration assay was performed on con/ovcar- 8 and siICAT/ovcar-8 cells to study ICAT effect on cell migration (Fig. 2). The scratch area was almost the same size in each experimental group at $0 \mathrm{~h}$. The area of migration cells in the MIS/AMH untreated control and ICAT gene silenced group had reached 81 and $63 \%$ at $48 \mathrm{~h}$. The area of migration cells in the MIS/AMH treated control and ICAT gene silenced group had decreased 22 and $57 \%$ at $48 \mathrm{~h}$. Compared with the control and ICAT gene silencing groups, cell migration was significantly reduced only by MIS/AMH treatment $(\mathrm{P}<0.05)$. The results showed that ICAT gene expression negatively correlated with ovcar- 8 cell migration ability, and MIS/AMH suppressed ovcar- 8 cell migration, which may be a result of the upregulation of ICAT gene expression.

ICAT siRNA inhibits apoptosis induced by MIH/AMH, but had no effect on cell cycle arrest. Flow cytometry clearly confirmed the reversal of ICAT on the apoptosis effect of MIS/AMH. After treatment of control cells with MIS/AMH, the cell population in $\operatorname{subG}_{0} \mathrm{G}_{1}$ and $\mathrm{G}_{0} \mathrm{G}_{1}$ phase changed from 1.1 to 18.9 and 69.8 to $62.2 \%$, respectively which was accompanied by a decrease from 9.1 to 6.2 and 19.8 to $12.5 \%$ in $\mathrm{S}$ and $\mathrm{G}_{2}$ phases. Exposure to MIS/AMH cells after ICAT siRNA silencing led to an increase in $\mathrm{G}_{0} \mathrm{G}_{1}$ to only $13.1 \%$ and a decrease of $G_{0} G_{1}$ to $68.8 \%$ while the $S$ and $G_{2}$ phases decreased 6.2 and $11.9 \%$ (Fig. 3). It showed significant difference only in the subG $\mathrm{G}_{1}$ phage $(\mathrm{P}=0.003)$ and showed no significant change in the other phages. We evaluated the occurrence of apoptosis by Annexin V/PI double staining apoptosis detection kit. As shown in Fig. 4, the percentage of apoptotic cells in the control group was $3.97 \%$ while the con/ ovcar- 8 cells treated with MIS/AMH had an apoptotic rate of $17.88 \%$ and the siICAT/ovcar- 8 cells treated with MIS/AMH showed $7.29 \%$ quantitative results revealed a significant difference between con/ovcar- 8 and siICAT/ovcar- 8 cells treated MIS/AMH cells.

Verification of the related protein by western blot analysis. To assess further the effect of ICAT on the MIS/AMH treated ovcar- 8 cells we performed western blots on the related proteins (Fig. 5). The expression of ICAT was increased after MIS/AMH treatment of con/ovcar- 8 but reversed by siICAT/ovcar- 8 whether MIS/AMH treated or not. Conversely, the decrease of apoptosis related protein pro-caspase-3 caused by MIS/AMH was reduced when siICAT/ovcar- 8 was added. This was accompanied by a concomitant decrease in cleaved caspase-3 and APAF-1. In contrast there was no change in the MIS/AMH inducement of E2F1. Similarly, p107 was uneffected by either treatment. The Wnt signaling pathway related 
A

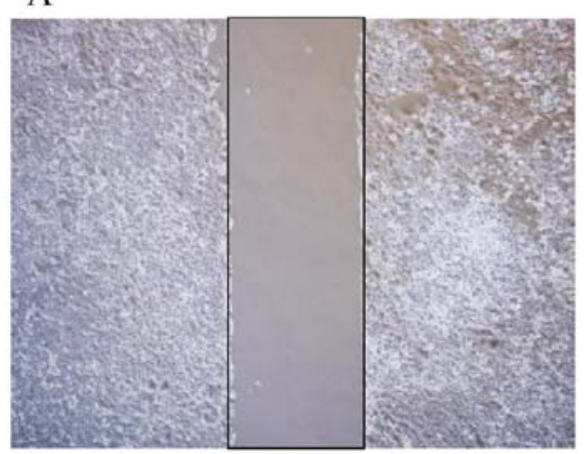

C

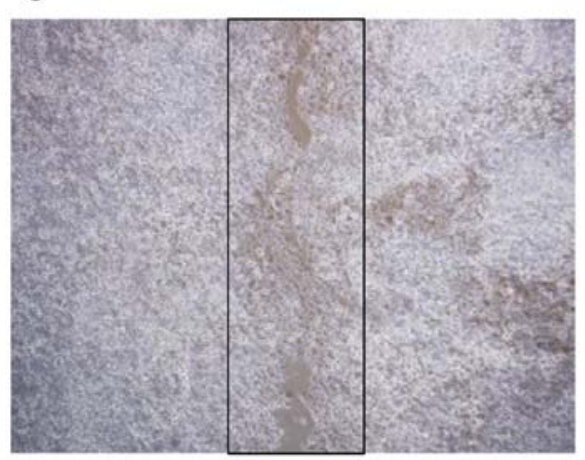

E

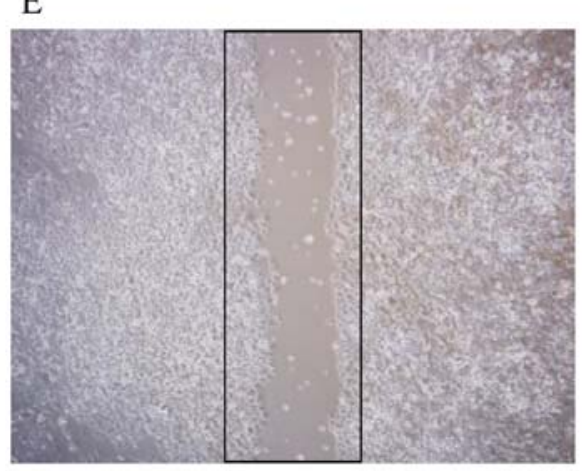

B

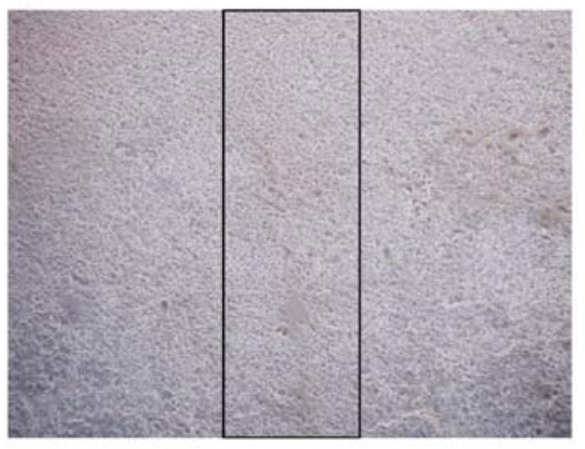

D
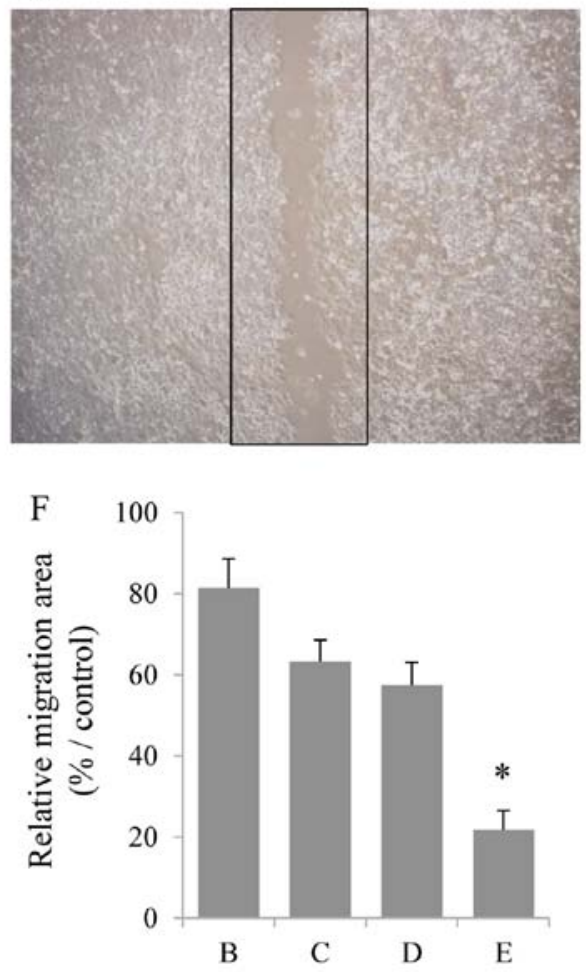

Figure 2. Scratch wound migration assay was performed to determine the motility of con/ovcar- 8 or siICAT/ovcar- 8 cells. Representative images of scratch wound migration obtained at $0 \mathrm{~h}$ (A), $48 \mathrm{~h}$ con/ovcar-8 (B), $48 \mathrm{~h}$ siICAT/ovcar-8 (C), MIS/AMH treated for $48 \mathrm{~h}$ in siICAT/ovcar-8 (D) and MIS/AMH treated for con/ovcar-8 (E). Bars indicate the mean \pm SD from three different experiments (F). Magnification, $\mathrm{x} 200$. ${ }^{*} \mathrm{P}<0.05$ compared with MIS/AMH untreated con/ ovcar- 8 group, $n=6$ per group.

protein, c-myc and phospho-c-Jun decrease by MIS/AMH treatment was unaffected by addition of siICAT/ovcar-8. $\beta$-catenin was slightly decreased by MIS/AMH, but ICAT siRNA increased to the control level again, this change was not statistically significant. However, there was no effect on the autophagy related protein, beclin-1 and ICAT siRNA had no effect on the MIS/AMH induction of LC3-I but significantly decreased LC3-II in ovcar-8 cells.

\section{Disccution}

A recent large-scale sequencing project (The Cancer Genome Atlas) profiled genetic alteration in 20 malignancies and identified signaling pathways. The Wnt signaling pathway was revealed as one of the key signaling pathways affected by tumorigenesis in three major gynecological cancers (21-23). Wnt signaling regulates developmental processes and cell growth and differentiation through $\beta$-catenin import into the nucleus where it activates transcription of target genes including cyclin Dl and $c$-myc (24). Within the Wnt signaling pathway, $\beta$-catenin and TCF/Lef- 1 complex represent primer targets for screening anticancer drugs as their deregulation is common in cancers (25). Expression of $\beta$-catenin and the TCF/Lef-1 complex was found to be increased in ovarian cancer, compared to the normal ovary suggesting a functional role for Wnt signaling in accelerating tumorigenesis (26). $\beta$-catenin interacting protein 1 (CTNNBIP1), also known as ICAT (inhibitor of $\beta$-catenin and TCF4), functions as a crucial node to mediate the cross-talk between E2F1 and $\beta$-catenin signaling. ICAT is a direct transcriptional target of E2F1, and activation of ICAT by E2F1 is required for E2F1 to inhibit $\beta$-catenin activity $(19,27)$. ICAT inhibits ovarian cancer cell proliferation and invasion, by inducing cell apoptosis and arrests cell cycle progression (28). 

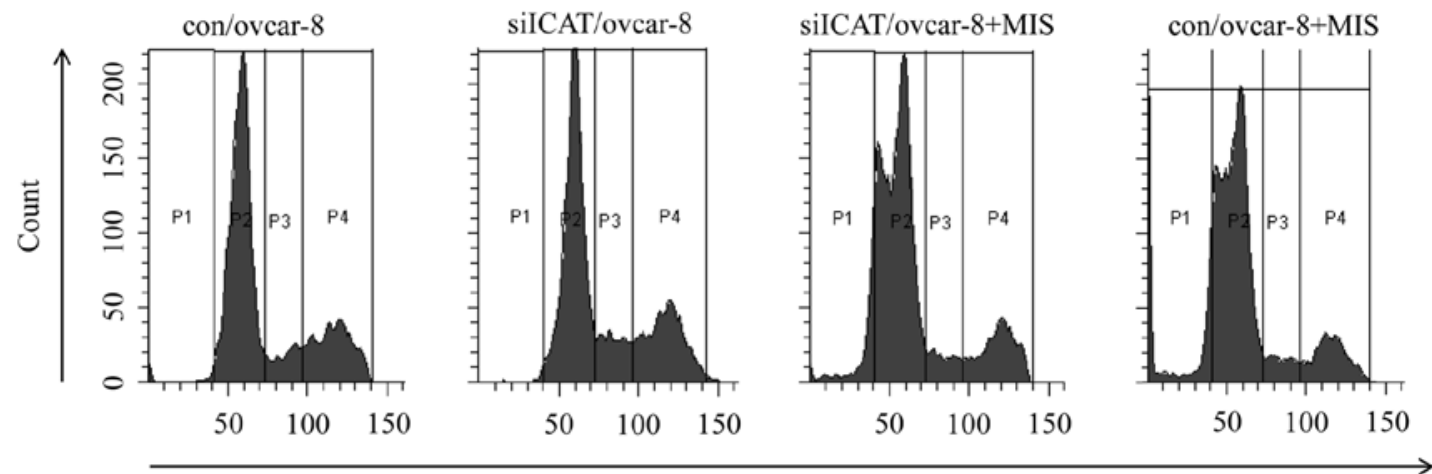

Propidium iodide

\begin{tabular}{ccccc}
\hline & $\mathrm{P} 1\left(\mathrm{subG}_{0} \mathrm{G}_{1)}\right.$ & $\mathrm{P} 2\left(\mathrm{G}_{0} \mathrm{G}_{1}\right)$ & $\mathrm{P} 3(\mathrm{~S})$ & $\mathrm{P} 4\left(\mathrm{G}_{2} \mathrm{M}\right)$ \\
\hline con/ovcar-8 & $1.1 \pm 0.16$ & $69.8 \pm 3.49$ & $9.2 \pm 0.31$ & $19.8 \pm 2.59$ \\
silCAT/ovcar-8 & $0.9 \pm 0.18$ & $66.1 \pm 4.26$ & $11.4 \pm 1.09$ & $21.6 \pm 3.74$ \\
silCAT/ovcar-8+MIS & $13.1 \pm 2.22^{*}$ & $68.8 \pm 3.10$ & $6.2 \pm 0.56$ & $11.9 \pm 1.40$ \\
con/ovcar-8+MIS & $18.9 \pm 1.33$ & $62.2 \pm 2.25$ & $6.2 \pm 0.17$ & $12.6 \pm 0.96$ \\
\hline
\end{tabular}

Figure 3. Cell cycle distribution after exposure to con/ovcar- 8 or siICAT/ovcar- 8 cells with MIS/AMH for 48 h. Propidium iodide stain was performed and analyzed by flow cytometry. Histograms of cellular DNA content were obtained by flow cytometry. ${ }^{*} \mathrm{P}<0.05$ compared with siICAT/ovcar- 8 treated MIS and con/ovcar- 8 treated MIS, $n=3$ per group.

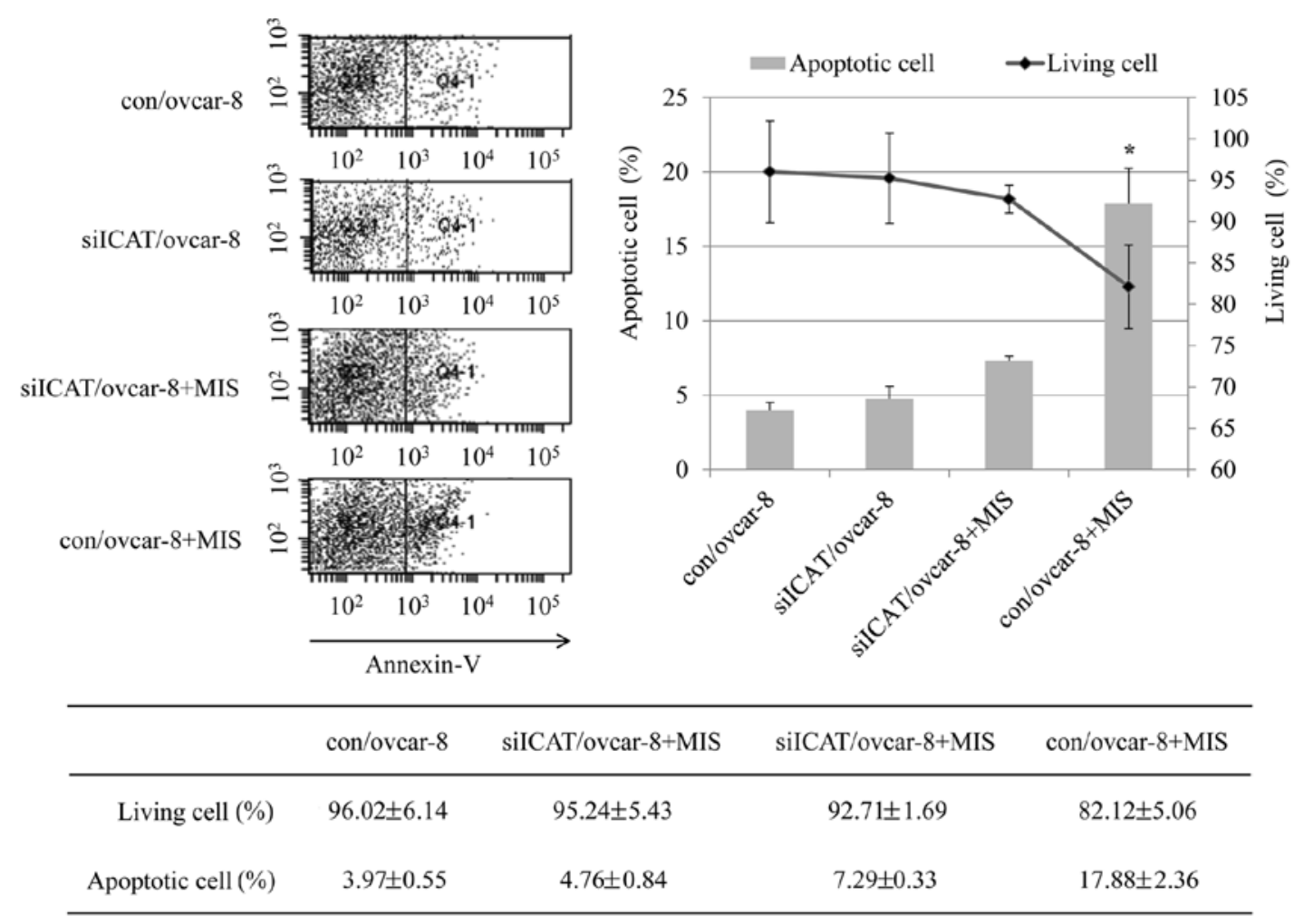

Figure 4. Apoptosis distribution after exposure to con/ovcar-8 or siICAT/ovcar- 8 cells to MIS/AMH for 48 h as assessed by externalization of phosphatidyl serine as measured by Annexin V-FITC binding using propidium iodide as a counterstain (left lower quadrant, surviving cells; right lower quadrant, early apoptotic cells). ${ }^{*} \mathrm{P}<0.05$ compared with MIS/AMH untreated group, $\mathrm{n}=3$ per group.

MIS/AMH inhibits cell growth and induces autophagy in gynecological cancer cell lines (29). A recent study shows that MIS/AMH-treated cells accumulated in the $\mathrm{G}_{1}$ phase of the cell cycle and subsequently underwent apoptosis in human epithe- lial ovarian cancer cells. Prolonged treatment with MIS/AMH downregulated the Rb-related protein, p107 and increased the $\mathrm{Rb}$ family-regulated transcription factor E2F1, overexpression of which inhibited growth (13). During MIS/AMH exposure, 


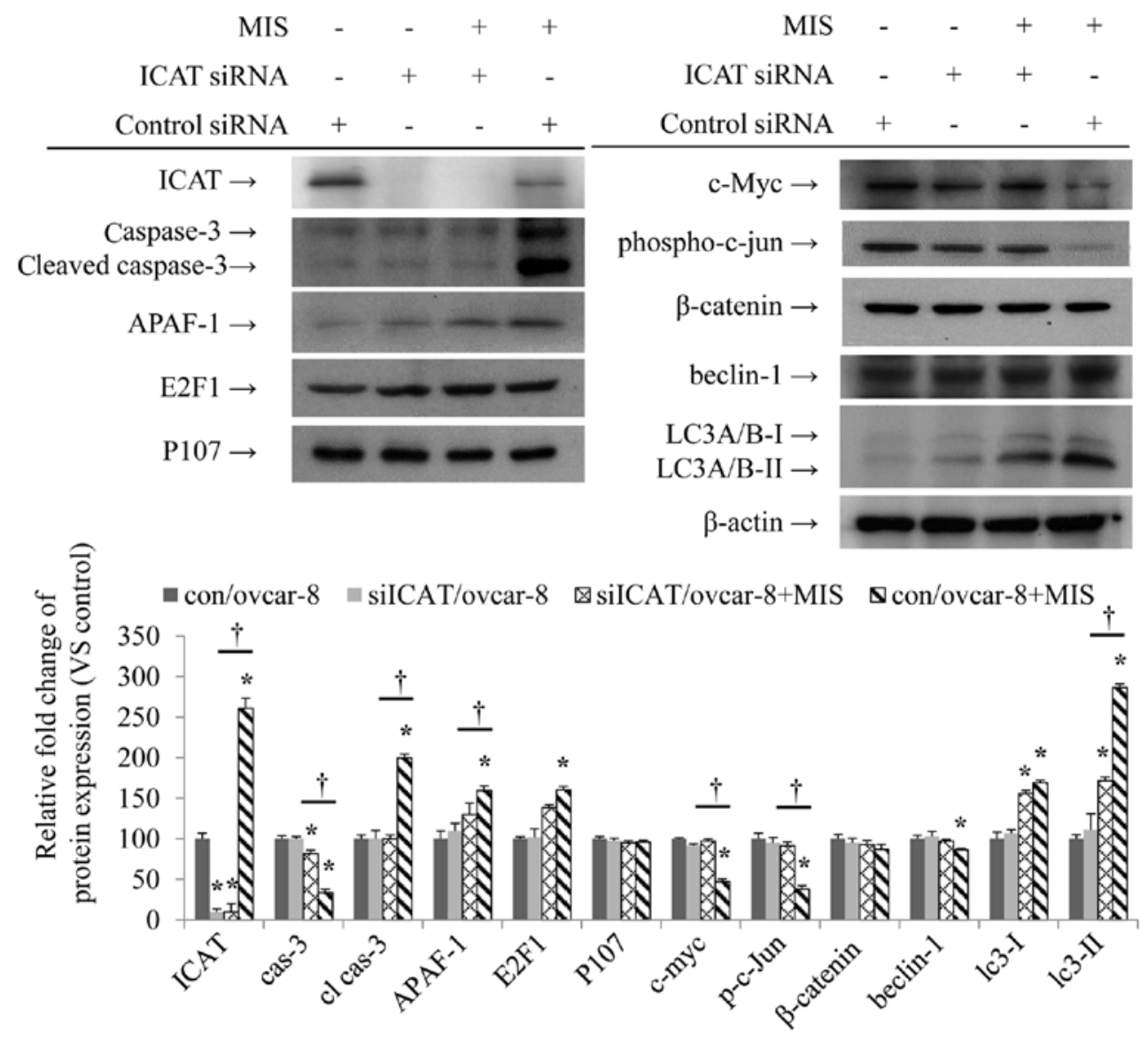

Figure 5. Western blot verification of apoptosis, cell cycle, and Wnt signaling pathway-related proteins in con/ovcar- 8 or siICAT/ovcar- 8 cells treated with MIS/AMH for $48 \mathrm{~h}$. The protein expression data are shown as the mean $\pm \mathrm{SD}$. ${ }^{*} \mathrm{P}<0.05$ compared with MIS/AMH untreated group, ${ }^{\circ} \mathrm{P}<0.05$ compared with siICAT/ovcar- 8 treated MIS and con/ovcar- 8 treated MIS, $n=3$ per group.

ICAT is upregulated by the proteins of E2F1 and the outcome of death, usually depends on the balance between the positive and negative apoptosis. Another study shows a number of major pathways included metabolism, signal transduction, cell growth and apoptosis in ovarian cancer cells (30). Among these pathways MIS/AMH is mainly responsible for the suppressive effect on cell cycle by regulating cyclin-dependent kinase (CDK) inhibitors and CDKs.

In the present study, we investigated whether MIS/AMH may regulate the $\mathrm{Wnt} / \beta$-catenin signaling pathway. The importance of Wnt-mediated growth, migration and invasion also was appreciated when cancer cell autophagy was observed after blocking Wnt/ $\beta$-catenin signaling pathway in breast and prostate cancer cells $(31,32)$ since autophagy is considered as a key mechanism of cell death in ovarian, cervical and endometrial cancers (33). In the present study, we demonstrated that the ICAT is upregulated in ovarian cancer cells when exposed to MIS/AMH where it reduces cell viability and induces cell cycle arrest, apoptosis and autophagy. ICAT downregulation by siRNA reversed the decrease in cell viability, migration and apoptosis induced by MIS/AMH. ICAT siRNA, however, had little effect on cell cycle or autophagy. The $\beta$-catenin, which is key molecule in the Wnt signaling pathway, was not significantly changed by treatment with MIS/AMH or ICAT siRNA. However, it has been reported that MIS/AMH cause $\beta$-catenin to accumu- late in the cytoplasm (34). In other words, according to the results demonstrated in this experiment $\beta$-catenin complex is inhibited with the TCF/Lef- 1 by ICAT. $\beta$-catenin, which could not go to the nucleus, does not act as a transcription factor and the expression of c-myc and c-jun is reduced, making it difficult to avoid apoptosis and this is confirmed by the increase of cleaved caspase-3 and APAF-1 by MIS/AMH. MIS/AMH induced ICAT led to apoptosis, thus, implicating the Wnt signaling pathway without affecting the cell cycle and autophagy related proteins, p107, beclin-1 and LC3-I. As LC3-II was significantly reduced by ICAT siRNA compared to MIS/AMH treated cells, additional studies are required to explore the role of ICAT on LC3-II. E2F1, an important transcriptional factor affecting cell cycle, was increased by MIS/AMH in both E2F1 and ICAT. However, no change in the treatment of ICAT siRNA could be found. Despite these results, it is still difficult to apply the mechanism that controls MIS/AMH to clinical practice. We are planning on creating ovarian cancer cell lines from patient-derived ovarian cancer samples and will proceed with research that further enhances the clinical approach. In other words, the data suggest that clinical studies should be evaluated in future to elucidate regulation of gene expression for MIS/AMH in ovarian cancer cases.

In summary, ICAT may serve as a tumor-suppressor in human gynecological cancer, suggesting it as a promising 
pathway that could be activated to suppress gynecological cancer. MIS/AMH inhibits the growth of ovarian cancer cell lines in vitro, suggesting a key role for this hormone in the biology human epithelial ovarian cancer. The present study implicates the Wnt signaling pathway as part of the downstream pathway mediated by MIS/AMH. The results of this study also suggest that MIS/AMH could synergize with therapies developed to inactivate the Wnt pathway, particularly in MIS/AMH receptor expressing cells such as ovarian cancer.

\section{References}

1. Miyamoto Y, Taniguchi H, Hamel F, Silversides DW and Viger RS: A GATA4/WT1 cooperation regulates transcription of genes required for mammalian sex determination and differentiation. BMC Mol Biol 9: 44, 2008.

2. Rey R, Lukas-Croisier C, Lasala C and Bedecarrás P: AMH/MIS: What we know already about the gene, the protein and its regulation. Mol Cell Endocrinol 211: 21-31, 2003.

3. Jost A: Problems of fetal endocrinology: The gonadal and hypophyseal hormones. Recent Prog Horm Res 8: 379-418, 1953.

4. Baarends WM, van Helmond MJ, Post M, van der Schoot PJ, Hoogerbrugge JW, de Winter JP, Uilenbroek JT, Karels B, Wilming LG, Meijers JH, et al: A novel member of the transmembrane serine/threonine kinase receptor family is specifically expressed in the gonads and in mesenchymal cells adjacent to the müllerian duct. Development 120: 189-197, 1994.

5. Barbie TU, Barbie DA, MacLaughlin DT, Maheswaran S and Donahoe PK: Mullerian inhibiting substance inhibits cervical cancer cell growth via a pathway involving p130 and p107. Proc Natl Acad Sci USA 100: 15601-15606, 2003.

6. Donahoe PK, Fuller AF Jr, Scully RE, Guy SR and Budzik GP: Mullerian inhibiting substance inhibits growth of a human ovarian cancer in nude mice. Ann Surg 194: 472-480, 1981.

7. Fuller AF Jr, Guy S, Budzik GP and Donahoe PK: Mullerian inhibiting substance inhibits colony growth of a human ovarian carcinoma cell line. J Clin Endocrinol Metab 54: 1051-1055, 1982.

8. Ferlay J, Steliarova-Foucher E, Lortet-Tieulent J, Rosso S, Coebergh JW, Comber H, Forman D and Bray F: Cancer incidence and mortality patterns in Europe: Estimates for 40 countries in 2012. Eur J Cancer 49: 1374-1403, 2013.

9. Bakkum-Gamez JN, Aletti G, Lewis KA, Keeney GL, Thomas BM, Navarro-Teulon I and Cliby WA: Müllerian inhibiting substance type II receptor (MISIIR): A novel, tissue-specific target expressed by gynecologic cancers. Gynecol Oncol 108: 141-148, 2008.

10. Song JY, Chen KY, Kim SY, Kim MR, Ryu KS, Cha JH, Kang CS, MacLaughlin DT and Kim JH: The expression of Müllerian inhibiting substance/anti-Müllerian hormone type II receptor protein and mRNA in benign, borderline and malignant ovarian neoplasia. Int J Oncol 34: 1583-1591, 2009.

11. Chung YJ, Kim HJ, Park SH, Yoon JH, Kim MR, Nam SW, MacLaughlin DT, Donahoe PK and Kim JH: Transcriptome analysis reveals that Müllerian inhibiting substance regulates signaling pathways that contribute to endometrial carcinogenesis. Int J Oncol 46: 2039-2046, 2015.

12. Tanwar PS, Commandeur AE, Zhang L, Taketo MM and Teixeira JM: The Müllerian inhibiting substance type 2 receptor suppresses tumorigenesis in testes with sustained $\beta$-catenin signaling. Carcinogenesis 33: 2351-2361, 2012.

13. Ha TU, Segev DL, Barbie D, Masiakos PT, Tran TT, Dombkowski D, Glander M, Clarke TR, Lorenzo HK, Donahoe PK, et al: Mullerian inhibiting substance inhibits ovarian cell growth through an Rb-independent mechanism. J Biol Chem 275: 37101-37109, 2000.

14. Namkung J, Song JY, Jo HH, Kim MR, Lew YO, Donahoe PK, MacLaughlin DT and Kim JH: Mullerian inhibiting substance induces apoptosis of human endometrial stromal cells in endometriosis. J Clin Endocrinol Metab 97: 3224-3230, 2012.
15. Anastas JN and Moon RT: WNT signalling pathways as therapeutic targets in cancer. Nat Rev Cancer 13: 11-26, 2013.

16. Madan B and Virshup DM: Targeting Wnts at the source - new mechanisms, new biomarkers, new drugs. Mol Cancer Ther 14: 1087-1094, 2015.

17. Chien AJ, Conrad WH and Moon RT: A Wnt survival guide: From flies to human disease. J Invest Dermatol 129: 1614-1627, 2009.

18. Masiakos PT, MacLaughlin DT, Maheswaran S, Teixeira J, Fuller AF Jr, Shah PC, Kehas DJ, Kenneally MK, Dombkowski DM, Ha TU, et al: Human ovarian cancer, cell lines, and primary ascites cells express the human Mullerian inhibiting substance (MIS) type II receptor, bind, and are responsive to MIS. Clin Cancer Res 5: 3488-3499, 1999.

19. Tago K, Nakamura T, Nishita M, Hyodo J, Nagai S, Murata Y, Adachi S, Ohwada S, Morishita Y, Shibuya H, et al: Inhibition of Wnt signaling by ICAT, a novel beta-catenin-interacting protein. Genes Dev 14: 1741-1749, 2000.

20. Lorenzo HK, Teixeira J, Pahlavan N, Laurich VM, Donahoe PK and MacLaughlin DT: New approaches for high-yield purification of Müllerian inhibiting substance improve its bioactivity. J Chromatogr B Analyt Technol Biomed Life Sci 766: 89-98, 2002.

21. McConechy MK, Ding J, Senz J, Yang W, Melnyk N, Tone AA, Prentice LM, Wiegand KC, McAlpine JN, Shah SP, et al: Ovarian and endometrial endometrioid carcinomas have distinct CTNNB1 and PTEN mutation profiles. Mod Pathol 27: 128-134, 2014.

22. Liu Y, Patel L, Mills GB, Lu KH, Sood AK, Ding L, Kucherlapati R, Mardis ER, Levine DA, Shmulevich I, et al: Clinical significance of CTNNB1 mutation and Wnt pathway activation in endometrioid endometrial carcinoma. J Natl Cancer Inst 106: 106, 2014.

23. Ford CE, Henry C, Llamosas E, Djordjevic A and Hacker N: Wnt signalling in gynaecological cancers: A future target for personalised medicine? Gynecol Oncol 140: 345-351, 2015.

24. Duchartre Y, Kim YM and Kahn M: The Wnt signaling pathway in cancer. Crit Rev Oncol Hematol 99: 141-149, 2016.

25. Chen HJ, Hsu LS, Shia YT, Lin MW and Lin CM: The $\beta$-catenin/ TCF complex as a novel target of resveratrol in the Wnt/ $\beta$-catenin signaling pathway. Biochem Pharmacol 84: 1143-1153, 2012.

26. Rask K, Nilsson A, Brännström M, Carlsson P, Hellberg P, Janson PO, Hedin L and Sundfeldt K: Wnt-signalling pathway in ovarian epithelial tumours: Increased expression of beta-catenin and GSK3beta. Br J Cancer 89: 1298-1304, 2003.

27. Wu Z, Zheng S, Li Z, Tan J and Yu Q: E2F1 suppresses Wnt/ $\beta$-catenin activity through transactivation of $\beta$-catenin interacting protein ICAT. Oncogene 30: 3979-3984, 2011.

28. Ono M, Yin P, Navarro A, Moravek MB, Coon V JS, Druschitz SA, Gottardi CJ and Bulun SE: Inhibition of canonical WNT signaling attenuates human leiomyoma cell growth. Fertil Steril 101: 1441-1449, 2014.

29. Borahay MA, Lu F, Ozpolat B, Tekedereli I, Gurates B, Karipcin S and Kilic GS: Mullerian inhibiting substance suppresses proliferation and induces apoptosis and autophagy in endometriosis cells in vitro. ISRN Obstet Gynecol 2013: 361489, 2013.

30. Nam SW, Jo YS, Eun JW, Song JY, Ryu KS, Lee JY, Lee JM, Maclaughlin DT and Kim JH: Identification of large-scale characteristic genes of Müllerian inhibiting substance in human ovarian cancer cells. Int J Mol Med 23: 589-596, 2009.

31. Li P, Guo Y, Bledsoe G, Yang Z, Chao L and Chao J: Kallistatin induces breast cancer cell apoptosis and autophagy by modulating Wnt signaling and microRNA synthesis. Exp Cell Res 340: 305-314, 2016.

32. Lin R, Feng J, Dong S, Pan R, Zhuang H and Ding Z: Regulation of autophagy of prostate cancer cells by $\beta$-catenin signaling. Cell Physiol Biochem 35: 926-932, 2015.

33. Orfanelli T, Jeong JM, Doulaveris G, Holcomb K and Witkin SS: Involvement of autophagy in cervical, endometrial and ovarian cancer. Int J Cancer 135: 519-528, 2014.

34. Xavier F and Allard S: Anti-Müllerian hormone, beta-catenin and Müllerian duct regression. Mol Cell Endocrinol 211: 115-121, 2003. 